\title{
Japanese encephalitis with Acute respiratory distress syndrome: A rare presentation
}

\author{
Kurane A.B. ${ }^{1}$, Kavthekar S.O. ${ }^{2}$, Bilagi V.R. ${ }^{3}$, Chougale R.A. ${ }^{4}$ \\ ${ }^{1}$ Dr. Anil Bapurao Kurane, Professor and HOD, Department of Pediatrics, ${ }^{2}$ Dr. Saiprasad Onkareshwar Kavthekar, \\ Associate Professor and Fellow in Pediatric Intensive Care Unit, Department of Pediatrics, ${ }^{3}$ Dr. Varun Ramchandra \\ Bilagi, Junior Resident, Department of Pediatrics, ${ }^{4}$ Dr. Roma Abhay Chougale, Professor and HOD Department of \\ Microbiology, all authors are affiliated with D.Y.Patil Medical College and Hospital Kolhapur, Maharashtra, India.
}

Corresponding Author: Dr. Varun Ramchandra Bilagi, Junior Resident, Department of Pediatrics, D. Y. Patil Medical College and Hospital, Kolhapur, Maharashtra, India. E-mail: drvarunbilagi@gmail.com

\begin{abstract}
A 15 years girl presented with high grade fever, headache, vomiting, loose stools, neck stiffness and positive Kernig's sign further more developed Shock with ARDS, landed in coma (GCS=3), with changing neurological signs, hemodynamically well managed and serum tested positive for JE virus, who later recovered without any neurological deficit.
\end{abstract}

Keywords: Acute respiratory distress syndrome, Japanese encephalitis, Nitric oxide

\section{Introduction}

Japanese encephalitis (JE) is the most important vaccine preventable cause of encephalitis in the Asia-Pacific region. As we all know JE is public health challenge due to its acute onset, fulminant course and high mortality and morbidity especially in children.50000 cases of JE occur worldwide/Year and 15000 of them die. Children $<15$ years of age are principally affected [1]. Domestic pigs [2] are reservoirs while the vector is Culex tritaeniorhynchus [3]. The case fatality rate among patients with encephalitis approaches $30 \%$, and approximately $30 \%-50 \%$ of survivors have long-term neurologic sequelae [4].

\section{Case Report}

A 15-yeargirl admitted with high grade fever associated with chills and rigors, loose stools (watery, non-foul smelling, 2 episodes, no passage blood/mucus), vomiting (non-projectile, non-bilious) \& headache for 1 day. On examinationPulse 80 beats/min, BP was 114/70mm of $\mathrm{Hg}, \mathrm{GCS}=15$, neck stiffness and positive kernig's sign was present. On investigating $\mathrm{Hb}=9.4 \mathrm{gm} \%, \mathrm{TLC}=13,600$ cells $/ \mathrm{mm}^{3}$ (N-78\%;L-20\%), platelets 2,13,000cells $/ \mathrm{mm}^{3}$; Dengue IgM, IgG \&NS1 was negative, CSF routine/microscopy showed protein $49 \mathrm{mg} / \mathrm{dl}$, sugar $65 \mathrm{mg} / \mathrm{dl}$, WBCs 3cells all of which were lymphocytes, CSF culture showed no growth. Patient was treated with Intravenous fluids, Inj. Ceftriaxone [100mg/kg/day] and antipyretics. On a subsequent day patient was delusional with each episode of fever, being normal between intrafebrile period and on next day $\mathrm{Hb}$ was $9.0 \%$, platelet to 51,000 cells $/ \mathrm{mm}^{3}$, PT/INR, a PTT, TT was within normal limits.BP was consistently low $\left(<50^{\text {th }}\right.$ percentile $)$ with wide-pulse pressure which was maintained within normal limits with support of intravenous fluids, Dopamine \& Noradrenaline and $\mathrm{O}_{2}$, Chest X-ray showed diffuse infiltrates and Ultrasonography showed IVC collapsibility was $30 \%$.Furthermore, patient was put on mechanical ventilator on $\mathrm{PCV}$ mode with $\mathrm{FiO}_{2} 90 \%$; $\mathrm{PEEP}=10$; PIP=14; SIMV Rate 20/min (GCS=7), ABG showed $\mathrm{p} / \mathrm{F}$ ratio of 190 and conscious level deteriorated in next 12 hours to $\mathrm{GCS}=3$, absent deep tendon reflexes and extensor planters. Clinically differential diagnosis at this time were Dengue shock syndrome and septic shock with Acute respiratory distress syndrome. (ARDS) Later patient's serum was sent for JE IgM ELISA to National Institute of Virology (NIV) Pune, which came positive.Patient deep tendon reflexes were present, later next day they were exaggerated, GCS=7. After 6 days of mechanical ventilation patient was weaned off $\left(\mathrm{FiO}_{2}=21 \%\right.$; PEEP=4; PIP=8; SIMV rate=20/min $)$ and was taken on SIMV-PC mode for one day and C-PAP for one 
day, $\mathrm{O}_{2}$ by nasal cannula for one day, then patient was off $\mathrm{O}_{2}$ and dopamine, noradrenaline on day 9 of admission. No obvious neurological deficit is seen but deep tendon reflexes were remained exaggerated. MRI also showed encephalitis changes which were consistent with JE.

\section{Discussion}

ARDS is associated with various disorders, among these, viral infections may be life-threatening. It is due to the viral lesions in the brain which were found in the cortex, pons, medulla, cerebellum, and spinal cord The brain stem lesions were predominantly in the ventral, medial, and caudal medulla. These areas have been considered to the central depressor or sympathetic inhibitory mechanisms in the vasomotor center, destruction of these areas causes an increase in the sympathetic drive causing systemic vasoconstriction and a shift of the blood to the pulmonary circulatory system leading to pulmonary edema [5]. These CNS lesions were previously observed in patients who died of Japanese B encephalitis [6].

There have been other mechanisms proposed for ARDS in patients with Japanese B encephalitis such as release of endogenous nitric oxide which is toxic to lung [7]. It is well known that nitric oxide exerts vasodilatory effects in various vascular beds. The production of nitric oxide through inducible nitric oxide synthase (iNOS) could reduce pulmonary hypertension. On the other hand, it may increase the oxygen free radicals and recruit more capillaries to increase pulmonary microvascular permeability. In this connection, it was found that endogenous and exogenous nitric oxide reduced pulmonary hypertension but increased the capillary filtration coefficient and the extent of injury. Nitric oxide production may be responsible for the pathogenesis of ARDS due to viral infection, and selective iNOS blockers may be therapeutic agents for ARDS induced by viral infections [5].

\section{Conclusion}

The ARDS in Japanese encephalitis is likely result of brain stem lesions. The production of nitric oxide through iNOS may also be involved in the pathological changes in the lung.

Funding: Nil, Conflict of interest: None initiated, Perission from IRB: Yes

\section{References}

1. Fischer M, Hills S, Staples E, Johnson B, Yaich M, Solomon T. 2008. Japanese Encephalitis Prevention and Control: Advances, Challenges, and New Initiatives, p 93-124. In Scheld W, Hammer S, Hughes J (ed), Emerging Infections 8. ASM Press, Washington, DC. doi: 10.1128/9781555815592.ch6.

2. Solomon T, Thao LT, Dung NM, et al. Rapid diagnosis of Japanese encephalitis by using an immunoglobulin M dot enzyme immunoassay. J Clin Microbiol. 1998;36(7):2030-4.

3. Robinson JS, Featherstone D, Vasanthapuram R, et al. Evaluation of three commercially available Japanese encephalitis virus IgM enzyme-linked immunosorbent assays. Am J Trop Med Hyg. 2010 Nov;83(5):1146-55. doi: 10.4269/ajtmh.2010.10-0212.

4. Allan R. Tunkel, Carol A. Glaser, Karen C. Bloch, James J. Sejvar, Christina M. Marra, Karen L. Roos, Barry J. Hartman, Sheldon L. Kaplan, W. Michael Scheld, Richard J. Whitley; The Management of Encephalitis: Clinical Practice Guidelines by the Infectious Diseases Society of America, Clinical Infectious Diseases, Volume 47, Issue 3, 1 August 2008, Pages 303-327, https://doi.org/10.1086/589747

5. Whitley RJ, Gnann JW. Viral encephalitis: familiar infections and emerging pathogens. Lancet. $2002 \mathrm{Feb} 9$; 359 (9305) : 507-13. DOI: 10.1016/S0140-6736 (02) 07681-X

6. GitaliKakoti, Prafulla Dutta, Bishnu Ram Das, Jani Borah, and Jagadish Mahanta. Clinical Profile and Outcome of Japanese Encephalitis in Children Admitted with Acute Encephalitis Syndrome. BioMed Research International, vol. 2013, Article ID 152656, 5 pages, 2013. https://doi.org/10.1155/2013/152656.

7. Raghava Potula, S. Badrinath, S. Srinivasan; Japanese Encephalitis in and around Pondicherry, South India: a Clinical Appraisal and Prognostic Indicators for the Outcome, Journal of Tropical Pediatrics, Volume 49, Issue 1, 1 February 2003, Pages 48-53, https:// doi.org/ 10. 1093/tropej/49.1.48

\section{How to cite this article?}

Kurane A.B, Kavthekar S.O, Bilagi V.R, Chougale R.A. Japanese encephalitis with Acute respiratory distress syndrome: A rare presentation. Int J Pediatr Res. 2018;5(11):596-597.doi:10.17511/ijpr.2018.i11.08. 